$\mathrm{SAD} / \mathrm{JSR}$

Sosyoloji Araştırmaları Dergisi / Journal of Sociological Research

Cilt / Volume 18 Sayı / Number 1 (Nisan/April 2015) : $(30-56)$

\title{
POLICE ACCOUNTABILITY SYSTEM IN ENGLAND AND WALES
}

\author{
Ercan BALCIOĞLU* \\ Erkan PALA $^{* *}$
}

\begin{abstract}
This article provides the reader with a literature review with the aim of finding out about the origin and system of police accountability in England and Wales. It is hoped that the article will help to identify some important conceptual considerations that ought to betaken into account by any professional and responsible police departments seeking to embrace accountability in its policing procedures.
\end{abstract}

This article explores the sensitive issue of police accountability to civilian oversight bodies in controlling police excesses. At the centre of the discourse lies the tacit acknowledgement that the enormous power and authority invested in the police does lead to corruption and excesses unless adequate checks and balances are installed.

Keywords: Police Accountability, Police Ethics, Police Integrity, Policing the Police, Civilian oversight bodies of Police.

\footnotetext{
* Yard. Doç. Dr., Polis Akademisi Başkanlığı, Suç Araştırmaları Merkezi (SAMER)

** Doktora Öğrencisi, Araştırma Görevlisi, Loughborough Üniversitesi
} 


\section{İNGILTERE VE GALLER'DE POLİS HESAP VEREBİLİLİK SISTEMI}

\section{ÖZET}

$\mathrm{Bu}$ makale, İngiltere ve Galler'de polis hesap verebilirlik, gözetim ve denetim sisteminin gelişimini bilimsel literatürü inceleyerek araştırmaktadır. Bu makaleyle hesap verebilirliği iç güvenlik hizmetlerinde önemli bir ilke kabul eden sorumlu, profesyonel ve demokratik iç güvenlik kurumlarına, bu alanda bazı önemli kavramsal değerlendirmelerin tanımlanması yoluyla yardım edilmesi umut edilmektedir.

İç güvenlik profesyonellerinin görevlerini yerine getirirken yetkilerini kötüye kullandıkları, her toplumda görülen bir olgudur. Bu makale, temel görevleri iç güvenlik kurumlarını gözetlemek ve denetlemek olan sivil gözetim organlarının İngiltere ve Galler'de kolluğun hesap verebilir olması için nasıl çalıştıklarını incelemektedir. Çalışmada kolluk üzerinde gerekli denetim ve denge mekanizmaları kurulmadığ takdirde, polise verilen yetki ve salahiyetlerin yozlaşmaya ve istismara yol açabildiği temel varsayımından hareket edilmiştir.

Anahtar Kelimeler: Polis Hesap Verebilirliği, Polis Suçları, Polis Etiği, Polis Bütünlüğü, Polislere Polislik Yapmak, Sivil Kolluk Gözetim Mekanizması. 


\section{WHAT IS ACCOUNTABILITY AND WHY IS IT IMPORTANT?}

The police's mandate in England and Wales or anywhere else in the world is to protect the public and to keep the peace. The ways in which governments attempt to attain these goals will vary from country to country but in many parts of the world, especially in the developed countries of Europe, a democratic society necessitates a police service that can protect the public under the rule of the law. The European Convention on Human Rights (ECHR), an agreement to protect human rights and civil liberties of individuals in Europe, requires public authorities such as the police to abide by the Convention. In cases where the police fail to follow Convention's standards, individuals can file a court-case to be investigated by the criminal justice system. Complainants have the choice of taking their cases to the European Court of Human Rights in Strasbourg, if domestic courts cannot resolve the case or fail to reach a fair verdict. Other than the ECHR, the UN Code of Conduct for Law Enforcement Officials (1979) asks police agencies around the world to comply with the fundamental rights set out in the UN Universal Declaration for the attainment of quality of life and to improve the status of police officers. In line with the international conventions, police forces in England and Wales are subject to the Police and Criminal Evidence Act 1984 (PACE). The PACE Act 1984 instituted a legal framework in relation to the powers and duties of the police, persons in police detention, criminal evidence, police discipline and complaints against the police. Criminal court cases for the prosecution of offenders are bound to fail if police officers are found to be not following the codes of practice, and any breach of correct procedures will amount to a disciplinary action. Nevertheless, despite the existence of such treaties and existing legislations, there have been vast numbers of instances in which the police's use of discretion in their assessment of situations were questioned. Their manner in upholding the law and safeguarding individuals' human rights and civil liberties have led to the vehement debates about accountability. In England and Wales for example, the case of Brazilian national Jean Charles de Menezes who was shot dead on an underground train in London in 2005 
when he was mistaken as a terrorist is of extreme importance as it re-ignited the arguments surrounding the manner police officers behave.

There are more striking examples than the wrongful shooting of Menezes: the police in the Nigerian state of Anambra stopped a motorcyclist and demanded to shoot the individual unless he gave 20 nairas (8 English pence in today's money) and when the motorcyclist refused, the police officer fired his gun and accidentally shot and killed a 22 year old woman (Stone, 2007:248); a blind 61 year old man was tasered by the police when his walking stick was mistaken for a samurai sword (The Guardian: 2012); and lastly, whilst writing this article, a quick visit to the BBC News website revealed a current news article with the headline "a 13-year-old boy carrying a replica assault rifle has been shot dead by police in the US state of California" (BBC News, 2013).

Police deviancy can be divided into two groups: 'bent for self' and 'bent for job' (noble cause corruption). The former includes misconducts that occur due to personal gain- bribery, violence and brutality, discrimination and so on-, whereas the latter occurs when officers violate laws and regulations to bring offenders to justice. Destruction of evidence, planting of evidence, and perjury are some of the examples that would fall under noble cause corruption which is argued to evolve out of an immense sense of loyalty to the policing job. Some serious police deviances are widespread but how do you go about reducing or even eliminating it?

The growing public awareness and concerns about the extent of police discretion and abuse of police powers have raised calls for effective accountability in operation. A shift to a greater global interest in police accountability has developed as a result for two main reasons. Firstly, the nature of policing has changed, and today's police officers are exposed to situations in which the decisions that they make can have serious impact on individuals' freedom and well-being. Professionalism, specialisation and technology have served to create a powerful police organisation with a greater control of what they do 
and how they deliver services of crime control and maintenance of peace, and thus there is a need to control the unwarranted deployment of coercive police powers. For most people both academics and the wider community, police accountability in practice means how the police are protecting the community and how they are treating citizens, but it is wider than that. Accountability mechanisms are a way of policing the police's many dimensions, encompassing police staff from grassroots to the highest rank- chief police officer. It involves the scrutiny of individual police officers and performance of police forces. With accountability, considered as the fundamental principal of a democratic society, individual police officers are required to give answers and take liability for their actions in matters involving both citizens or police officers (for example, mistreatment of officers by other colleagues). Agency-level accountability, on the other hand, involves the performance of local police forces in respect to meeting the demands of the government. An effective accountability system is desired by many states as it has become increasingly recognised that lawfulness and legitimacy are essential for the control of crime and maintenance of peace. The theory is that by having eyes watching over the police's shoulder, the police would be significantly more likely to comply with the law: were appropriate systems not in place, police officers would be more likely to create, sustain and shield police deviancy. Secondly and equally importantly, accountability is essential for the maintenance of public's faith in the police (Walker, 2005:42). Effective accountability systems leads to the legitimacy of the police: the concept of 'policing by consent'- where the public accept the police's authoritywould be threatened otherwise. Policing by consent is essential if the police are to reduce crime and keep the public's peace. After all protecting the public and controlling crime and disorder is an unrealistic quest for the police organisation alone. This vision has been iterated excessively in the policing literature, most recently in the report of the Independent Police Commission: Policing for a Better Britain. Over half a century ago, Reith (1956) emphasised that if positive relationships are withdrawn for one reason or another, the police would be helpless and would cease to function. They 
would be 'powerless' over the most transparent illegality in our streets because police efficacy is almost entirely determined by the co-operation given to them by the public. The validity of Reith's (1956) statement is appreciated when we consider that over $75 \%$ of arrests made by the police occur due to the intelligence gained by the public (Black, 1970 cited in Shotland and Goodstein, 1984:9)

\section{THE TRI-PARTITE ACCOUNTABILITY MECHANISM IN ENGLAND AND WALES}

In the 19th and well into the 20th century, borough police forces in England and Wales were controlled by the local government rather than centrally. This structure placed the Home Office in an uncomfortable position. The problems were mainly due to two reasons: a lack of faith and trust in the local government and second, the possibility of left-wing involvement in policing affairs. The state attempted to gain control of police forces through the excuses of 'efficiency', 'economy' and 'security' but these have failed. This weak system of accountability was ultimately scrapped under the Police Act 1964 when high-profile corruption scandals involving borough police forces where brought to light by the Royal Commission. Since the Police Act 1964, the 43 police forces of England and Wales are held to account through the tripartite system of police governance and accountability. Tripartite because the responsibility of policing affairs is distributed between three (tri) parties: Home Office, chief constables and Police and Crime Commissioners (PCCs). Under the tripartite structure, the Home Office is answerable to the public and Parliament for the overarching police efficiency and effectiveness. It is within the Home Secretary's remit to determine key national policing objectives; produce national policing plans; take remedial action against individual forces if inspection reports judge them ineffective; approve appointment of chief police officers; and issue statutory codes of practice and directions to both PCCs and chief police officers. The second body of the tripartite system, chief police officers, are responsible for the control and directing of their assigned police forces. This involves preparing a local policing plan in partnership with PCCs; working towards 
meeting the local and national policing objectives; allocating resources; and recruiting police personnel. PCCs on the other hand are accountable to local communities and the Home Secretary. They replaced police authorities under the Police Reform and Social Responsibility Act 2011 to be the powerful voice of communities; to set local policing priorities through consultation with communities; determine budget allocation in collaboration with chief police officers under the Home Office's Best Value programme; bring together community safety and criminal justice partners; and to appoint the Chief Constable, hold them to account for running the force, and dismiss them if necessary. What led to the demise of police authorities is the notion that they were ineffective in representing communities (Home Office, 2010). Not only did they remain invisible according to the Home Office, the public did not know how to influence local policing priorities: the Home Office citizenship survey found that only $43 \%$ of the public felt that they had some control over the decisions affecting their local area (Home Office, 2003).

Nevertheless, what can be safely asserted is that there have been enduring debates about the 'equal' separation of power between the three parties under the tri-partite system. Over the last decade or two, the shared responsibility of holding the police to account has been deemed to shift the locus of power more towards the 'centre', pushing chief constables and especially police authorities to a side (Flanagan, 2008; Berry, 2009; Home Office, 2009) serving to detriment local democratic accountability (Mawby and Wright, 2005:10). The Home Office has been argued to be excessively involved in the provision of local policing. For example, the remit to approve newly appointed chief police officers, or the power to require chief police officers to retire or resign for greater 'efficiency' in service is deemed to reduce the role of PCCs in the tripartite system. And more importantly, following the inspection reports which stressed the need for a 'performance culture', the Conservative government introduced centrally set targets. Having the Home Office issuing performance targets to 
police forces meant that the tripartite system is no longer based on equal separation of power and responsibility but it is rather a subordinate structure. This vision is also held by the Local Government Association (2008:6):

The Home Secretary's powers through the setting of priorities and targets via the National Policing plan plus those resulting from the funding and audit and inspection regimes dwarf those of the police authority. The result is that the police authority is now much the weakest pillar in the tripartite structure ... The consequence of the gradual weakening of police authorities over the 40-year period since the passing of the Police Act, is that the connection of the police to their local communities has been severely reduced. As a result the Home Secretary is the only visible politician who can be called to account for the way the police work.

Together with the centrally set targets, the Police Performance Assessment Framework (PPAF) was introduced in April 2004 by the Home Office in consultation with the Association of Chief Police Officers (ACPO) and Association of Police Authorities (APA) to 'provide an effective, fair framework for comparing police performance and provide a firm basis for effective performance management'. (Home Office, 2003:14). Comparisons can be made between forces on satisfaction levels, trust and confidence in the police, clear up rates, response rates and etc. But not only limited to those measures, PPAF allowed police forces to be held accountable for their performance (Mawby and Wright, 2005:7). Police forces' performance reports have led to vehement debates, frequently sparked by the media and the politicians. Academics' growing interest in PPAF led to the conclusion that performance targets have not only prevented local innovation and autonomy but they have skewed policing priorities and tempted officers into using their time in unproductive ways or into directly fiddling performance figures. Unrealistic productivity targets (certain number of arrests, stop and searches, 
clear-up rates, etc.) set to police forces can inadvertently encourage police corruption. The amount of time that is spent on meeting targets at the expense of catching serious offenders who pose a greater threat to the public has created a growing fury in society. In 2010, it was reported that the town halls and police forces across England and Wales had raised $£ 330$ million in parking fines, $£ 100$ million from speeding tickets and $£ 12$ million from spot fines (Daily Mail, 2010) for offences that range from littering to other "ludicrous" misdemeanours such as putting out bins on the wrong day, possessing a plastic toy pistol, feeding birds, or simply for throwing a cucumber at another person (BBC News, 2007). In an attempt to allow greater local innovation and autonomy for the police to concentrate more on areas concerning them, and also in order to abandon the use of performance data to name and shame failing agencies, the current Home Secretary, Theresa May, announced the abolition of targets (The Independent, 2010).

The controversy surrounding today's tripartite system does not end there. Although the theory behind the introduction of PCCs is to simplify the system and help drive a better service delivery by giving the public a louder voice in policing by democratically electing their police representatives, it is argued that the PCC initiative leads to the loss of diversity of skills, experiences and the voices that police authorities had initially offered. Police authorities typically had 17 members (9 from local government, 5 local 'independents' and 3 magistrates), and thus the power of 17 members is going into just one individual. Having one person responsible to oversee the work of the police can make a real mess, especially if the position falls into the hands of a person who has no genuine interest in the police or has no background in the police. Thus, there is now the increased possibility of the police losing interest in crime issues that affect minority groups such as hostility towards the police, grooming, early and forced marriages, etc... in order to deal with crimes that are of greater concern such as burglary and anti-social behaviour. An analysis of national PCC demographics is essential to 
determine whether they reflect the diverse community whom they are supposed to represent. Having this in mind, prior to the police authorities' termination, $9.5 \%$ of all police authority members were from ethnic minority (ethnic minorities constitute $8 \%$ of the total UK population) and $30.3 \%$ were women (CLINKS, 2012). Although there were twenty ethnic minority candidates for the PCC position, none were elected. Only one in seven of PCCs are women. Although all parties have made a pledge to enhance diversity, this pledge does not seem to apply to the candidates for police and crime commissioners. Moving on from this lack of representation, a closer look to the PCCs' previous work experience shows that seven elected PCCs have served in the military; five were magistrates; and eight were former police officers (Parliament, 2013). But more controversial than that, many scholars along with civil rights groups such as the group Liberty have argued that the replacement of police authorities with PCCs would attract politicians and law-and-order populists. Indeed this has been the case: of the 192 candidates who stood for the 41 positions (each worth over at least $£ 75,000$ in annual salary), the Conservatives managed to get 16, Labour 13 and Independents 12 posts (BBC News; 2012). Strikingly, an English Defence League (EDL) member, too, was standing for the position in Bedfordshire. Although there are barriers that are intended to stop individuals standing for the position if they have been convicted of an imprisonable offence, there are no barriers to stop extremists who have not been charged for any offence. To make matters worse, there is a very good chance of PCC seats falling in the wrong hands because the majority of the public have shown little concern to vote for their local PCC or were not aware of PCCs. In the 2012 PCC elections for example (at a financial cost of $£ 100$ million to the government (amounting to $0.15 \%$ of total police funding), less than $15 \%$ of those eligible to vote could be bothered to vote, sparking furious debates about accountability, democracy and PCCs' legitimacy. The record for the lowest turnout was recorded in European Parliament elections in 1999 with only $23 \%$ of the public voting. Other than the arguments that question the legitimacy of the new commissioners, many have argued that a politicised police stands in 
contradiction to the foundations of contemporary policing laid down by Sir Robert Peel in 1829 who favoured police independence from politics and argued that British police were not the tool of the government but rather were the public's police. Just one of the inevitable limitations of a politicised police is that:

A politicised police force brings the power of the police and police-government relations into play in a way that has negative consequences for accountability. Police power is increased when the Force receives almost unconditional backing from government. Even if an oversight body is dedicated to ensuring effective oversight, when its aims conflict with the mutual objectives of police and government it will find it extremely difficult to deliver effective accountability (Lewis, 1999:119).

The coalition government's police and crime commissioner initiative which came into force in November 2012 aims to make police forces more accountable to the community, through the greater involvement of citizens in democratically electing their police representative. This arrangement may encourage police forces to be more community-orientated; work directly with communities to identify their policing priorities and tackle problems that concern them. Although PCCs represent a dramatic change in police accountability, their impact on accountability, local policing and crime will vary from region to region. PCCs extent of impact is yet to be seen and is still an open question. Thus at this moment of time, evaluating the real impact of PCCs remains beyond the scope of this paper.

\section{OTHER MECHANISMS}

The tripartite accountability mechanism, as discussed above, fails to recognise the organisational accountability that is available in every regional police force: police officers at any rank are held accountable through the hierarchical rank structure found in every police force. The hierarchical rank structure in English and Welsh police forces is quasi-military, with the aim of creating a disciplined, systematic and answerable service. The ranks within police forces (except MET) are as follows in ascending order of seniority: police constable; sergeant; inspector; chief inspector; superintendent; 
chief superintendent; assistant chief constable, deputy chief constable and chief constable- the most senior police officer. Police officers are expected to be supervised by their upper ranks. If police misconduct has taken place, higher ranked officers are required to investigate and take disciplinary action if deemed necessary. As well as the organisational accountability, police forces are accountable to various exterior bodies:

\section{HER MAJESTY'S INSPECTORATE OF CONSTABULARY (HMIC)}

It is within the Her Majesty's Inspectorate of Constabulary's (HMIC) remit to carry out annual inspections of 43 territorial police forces in England and Wales with the aim of encouraging improvement, and report the findings to Parliament. HMIC is independent of the government and the police: inspectors are appointed by the Crown with the power to seek information from police forces and full access to the premises as set out in Section 54 of the Police Act 1996. Besides police forces, HMIC has, relatively recently, been given the responsibility to inspect other forces and organisations such as the Armed Forces Police (Royal Navy, Royal Military, Royal Air Force Police), British Transport Police, Ministry of Defence Police, Police Service of Northern Ireland, and the National Crime Agency. It is within the HMIC's decision to determine the depth of investigation and the frequency of visits to these organisations. The first inspectors of constabulary were appointed under the County and Borough Police Act 1856. Although the wording of HMIC's core functions have changed over the years, the principles remained intact since its inception:

Through inspecting, monitoring and advising, to promote and advance improvements in the efficiency and effectiveness of policing. We will do this independently, professionally and fairly, always championing the public interest, and we will explain what we do and why.

In addition to the chief inspector of constabulary, there are currently four other inspectors of constabulary with regional responsibilities. Inspectors' work is assisted by support personnel. HMIC 
deploys various tactics in their inspections- such as 'watchdog' tactics, public consultation, etc. The reports which illustrate the performance of police forces are accessible by the public from the day they get published on their website. The theory is that by publicising the reports, the public will be able to see what and how their local police are doing, putting pressure in those forces lacking in efficiency and effectiveness to enhance their game.

\section{THE POLICE STANDARDS UNIT}

The Police Standards Unit (PSU) was set up by the then Home Secretary David Blunkett in July 2001, but was formally established under the Police Reform Act 2002. The motive behind its introduction is to improve police performance and reduce crime and disorder by identifying successful policing practice and disseminating its execution across England and Wales. If a force is identified as needing intervention due to poor performance, the Home Office's PSU will step in to provide assistance at any level: from top police office to deprived neighbourhoods. The intervention is normally the result of HMIC's inspection. Although the introduction of PSU may translate to increased centralisation of policing for some (as the Home Office is given more and more reasons and powers to intervene), it is on the other hand argued that the PSU will have an imperative role in reducing variations between territories in policing and crime rates by allowing other forces to benefit from policing strategies that have been shown to work.

\section{INDEPENDENT POLICE COMPLAINTS COMMISSION (IPCC)}

The Independent Police Complaints Commission is an independent organisation funded by the Home Office with a statutory responsibility to oversee the investigation of police misconduct filed against the police (as well as the Serious Organised Crime Agency, British Transport Police, HM Revenue and Customs and the UK Border Agency) as set by the Police Reform Act 2002. The IPCC came into existence on April 2004 after replacing the Police Complaints Authority (PCA) which was set up in 
1984. The PCA failed to attain public's trust and faith in the complaints system, in part because of continued questioning of its independence and also because of the high standard of evidence required to reach a conclusion. Calls for greater effectiveness, especially after the Macpherson report, led to the creation of the IPCC. Although the IPCC is completely funded by the Home Office, it remains a nondepartmental public body meaning that it is entirely free from pressure groups, politics, police and, in principle, government. Under the Police Reform Act 2002, the police forces are required to record all complaints that individuals make against police officers within ten days. The Complaints and Misconduct Units, overseen by the deputy chief officers, are responsible for dealing with public complaints internally. If individuals are not happy with the way that their complaint was dealt or if they are not happy with the outcome, they can appeal to the IPCC. In scenarios where the complaint is serious, such as deaths in custody, shooting incidents etc., it is mandatory for police forces to refer them to the Commission. To be on the safe-side, the IPCC has the powers to step-in when they deem there is a serious public concern. It is also worth noting that there are four modes of investigation carried out by the IPCC: local investigation (carried out entirely by the police with the complainant's permission); supervised investigation (where the IPCC sets out terms of reference for the police); managed investigations (carried out under the direction and control of the IPCC); and independent investigations (carried out entirely by the IPCC's own investigators and overseen by a Commissioner). The cost of independent investigations range from $£ 45,000$ to $£ 300,000$, and between 2008 and 2011 , only 104 independent and managed investigations were carried out. Out of the 104 investigations, the IPCC referred 47 cases to the Crown Prosecution Service for judicial action (IPCC, 2012: 9). In comparison to the IPCC, a total of 29,639 complaint cases were finalised by police forces in 2011/2012 (14\% less than the previous year), and 6,339 appeals were made to the IPCC (3\% increase when compared against last year). Of 6,339 appeals made to the IPCC, 1,374 were based on the notion that the police forces had not recorded their complaint; 426 cases were appeals made against local 
police force's investigation outcome; and 4,539 were investigation appeals made to the IPCC (IPCC, 2012a: 7).Following the police scandals, as highlighted earlier, the IPCC was also required to enhance public confidence in the complaint system but this became a struggle as a result of its increasing workload and tightening funds. Deductions in funding and increasing workloads have forced the Commission to conclude "the Commission does not currently have sufficient resources to enable it to meet its statutory responsibility or the public's growing expectations of its role" (House of Commons, 2013, para21). It is ironic that the IPPC's budget falls below that of the Metropolitan Police's Professional Standards Department (House of Commons, 2013: para8). With the redundancy of 63 Commission employees over the last years which equates to $15 \%$ of the workforce (House of Commons, 2013, para21), it is perhaps understandable that it takes 26 weeks for an appeal to be completed (House of Commons, 2013, para16). The IPCC altered its Statutory Guidance in April 2010 with the intention of making investigations more proportionate and fair by no longer requiring substantial evidence to prove a misconduct. Instead:

"Complaints subject to an investigation are judged in terms of whether they are 'upheld'. A complaint should be upheld where the findings of an investigation show that the service provided was below the standard a reasonable person could expect" (IPCC, 2011:3).

It has been anticipated that the new system of handling police complaints would lead to a growth in the number of complaints made against police officers, but this was not the case in 2011/2012 as shown above. More to the point, it is anticipated that this change is an important step if the public's confidence in the police is to be enhanced: the way the police handle individuals' complaints is a key factor in determining public satisfaction in the police. Leaving aside the benefits of such change, there is one issue however which has been reoccurring for almost half a decade: investigation of police 
officers by other police officers. As underlined earlier, the majority of complaints against police officers get investigated internally within police forces: of 30,143 complaints made against the police, only 6,339 made it to the IPCC (IPCC, 2012b:15). As in the words of Goldstein (1977 cited in Lewis, 1999:29) "it is absolutely unrealistic to expect officers on special assignment, however honest and dedicated, to investigate zealously the activities of fellow officers who may one day be their partners or superior". According to Walker (2005), following Goldstein's (1977) argument, it is also unrealistic to expect police officers to investigate former partners who they have shared good and bad memories with. Walker (2005) sees this similar to asking brothers and sisters to investigate each other or their parents. In support of Goldstein (1977) and Walker (2005), the appeals made to the IPCC following an in-house police investigation of corruption revealed that the $31 \%$ of cases investigated by the police were misjudged in 2011/2012. Goldstein (1977) and Walker's (2005) attitude towards internal examination of police misconduct is however largely disregarded by the police, who often claim that police officers have the practical experience and the relevant knowledge- familiarity with the criminal law and presenting their investigations to the CPS and the courts-, and thus are equipped with the right skills and techniques to judge the misconduct of other police officers. It is well documented that police officers in England and Wales have attempted to protect their colleagues when they are guilty, such as in the Stephan Lawrence and Hillsborough cases, ultimately serving to frustrate and anger the public. This police-centred approach towards investigation of officers undermines the democracy aspect of the British accountability system. Nonetheless, even the IPCC is staffed by the individuals that they are supposed to be investigating bringing in the arguments that IPCC is not adequately independent from the police service: about $11 \%$ of all staff and $33 \%$ of investigators are former police officers (House of Commons, 2013b:24). The Police Reform Act 2002, asserts that the IPCC should maintain an "appropriate degree of independence" (cited in House of Commons, 2013b:24) but it has not clarified what is actually meant by "appropriate". 


\section{NATIONAL AUDIT OFFICE}

Similar to the IPCC, the National Audit Office (NAO) is an independent body funded by the Home Office for the responsibility of financial investigation of bodies funded by the United Kingdom Parliament, which also includes the police service. Although the Home Office determines the total budget allocated to each police force, the allocation of that fund to police officers and civilian staff, equipment, buildings, vehicles, and maintenance is negotiated between PCCs and chief constables. This decentralised method of allocating funds is said to facilitate a greater amount of local managerial freedom (Newburn and Jones, 1996) which can lead to the achievement of local policing priorities, and thus increasing local accountability (Mawby and Wright, 2005:8). Between 2012 and 2013, the NAO has scrutinised the expenditures of central government departments, government agencies and non-departmental public bodies whose revenue amounted to over $£ 1$ trillion. In addition to financial auditing, the other strand of the NAO includes 'value for money': looking at how government projects, programmes and initiatives have been implemented (NAO, 2014).Each year around 60 reports are published for the attention of Parliament. The necessity of a financial audit office is obvious: police forces are provided with huge revenue to provide security and harmony. The 43 police forces across England and Wales had $£ 12$ billion funding from taxation in $2013-2014$, and $72 \%$ of this funding came from the central government (NAO, 2014a: 5). The remaining funding is covered by the Department for Communities and Local Government or the Welsh Assembly Government. Despite the theoretic validity of the NAO, some concerns have been raised regarding its accountability and independence. For example, in scenarios where the report is too politically sensitive, they may not get published. This can be successfully illustrated when the NAO was not published in 1992 following an investigation into the Al Yamamah military arms deal between members of the Saudi royal family and British government officials which involved bribery. Further criticisms stem from the notion that the NAO's reports are insufficiently strategic, with a lack of transparency. The NAO's reports get 
published following a review by teams of academics from Oxford University and the London School of Economics. The committee takes into account the reliability, validity and conclusions of the reports and makes amendments if they are perceived to be lacking in intellectual analysis.

\section{THE EXTENT OF POLICE CORRUPTION IN ENGLAND AND WALES}

Under the previous headings, the complex structure of the police accountability system in England and Wales has been discussed. Despite the accountability system being renowned for its fairness, democratic elements and effectiveness with the existence of legal Acts, rigorous checks by independent bodies and equal separation of power between different partners, police accountability remains an unsolved policing area. As it was boldly hinted above on numerous occasions, gaps in the successful deployment of police accountability have been shown to undermine it. Such as in the case of Brixton riots when Scarman (1981) reported that 'Operation Swamp 81' which was introduced by the Metropolitan Police to tackle street crime through the police's manipulation of their powers of stop and search 'was a serious mistake' when the police overwhelmingly targeted ethnic minorities due to their prejudicial views; or in the findings of the Hillsborough Independent Panel which followed the incident that led to 96 deaths on April 1989 at the Hillsborough Stadium in Sheffield during the football match between Liverpool and Nottingham Forest found that South Yorkshire Police not only made basic mistakes when controlling fans but they have also intentionally attempted to cover-up their mistakes. Perhaps more strikingly, Macpherson's investigation into the racist murder of a black teenager, Stephen Lawrence confirmed allegations of systemic corruption and institutionalised racism within the police organisation (Home Office, 1999). Macpherson's report is so important that it contributed to the creation and passing of the Criminal Justice Act 2003 that altered the centuries-old principle of double jeopardy. Hence, police corruption proves to be a stubborn problem for many police forces across England and Wales: a continuing issue with no quick fix. But what is thoughtprovoking is that it is difficult to determine the true extent of police corruption due to high levels of 
police discretion; low managerial and public visibility; and lack of accountability. Sceptical researchers have used Sir Robert Mark's move where he dismissed over 400 corrupt officers when he was the commissioner of the Metropolitan Police (1972-1977) to exemplify the pervasiveness of police deviance in England and Wales. It would be illogical however to use this example and generalise this to the 42 other police forces.

The IPCC's research into police corruption gives us an idea of how widespread police corruption is, but it must be born in mind that the IPCC's findings are inadequate to determine the true extent because; not every citizen files a complaint against a police officer; not every complaint gets recorded; and importantly, as discussed above, not all corruption investigations are judged professionally. Despite such factors which may diminish the real severity of the problem, corruption allegations against police officers continue to this day in big numbers. During 2011/2012, for example, 30,143 complaints were made against police officers, a fall of $9 \%$ when compared against 2010/11 figures and representing a 12\% decrease since 2009/10 (IPCC, 2012b:5). In the same year period, 54,714 allegations were recorded by the police forces across England and Wales, representing an $8 \%$ decrease compared to 2010/2011 (IPCC, 2012b:5). The number of allegations is significantly higher than the number of complaints. This is simply because a single complaint may contain more than one allegation (for example, a person may accuse the police officer for using excessive physical force and for being rude at the same time. Of those who were subject to a complaint, $73 \%$ were Male and $24 \%$ were Female (3\% unknown), and interestingly $89 \%$ were White, $2 \%$ were Asian and only $1 \%$ were Black (IPCC, 2012b:28).Police officers were mostly accused of the following types of corruption: 'other neglect or failure in duty (28\%), incivility, impoliteness and intolerance (17\%), other assault (11\%), oppressive conduct or harassment (7\%), and unlawful/unnecessary detention (5\%) (IPCC, 2012b:5).The frequency of police-corruption directly affects police legitimacy. A survey carried out 
by the HMIC (2011:9) found that around a third of respondents felt that police corruption was common and remained a big problem for the police. The public may have valid reasons to believe so when considering the vast number of fatalities involving the police. In 2011/2012 alone there were 18 road traffic fatalities; 2 fatal police shootings; 15 deaths in custody (almost half identified as having mental health problems and $38 \%$ were from black or minority ethnic groups); 47 other deaths following police contact; and 39 suicides following police custody (IPCC, 2012c: 5-10).

\section{THE PROTECTION OF GUILTY POLICE OFFICERS BY THE STATE}

It is in a way understandable when the police do not successfully investigate "one of their own" when they are facing an allegation but it is important to underline that the punishment of individuals following a misconduct can serve to deter other police officers from committing an offence because they may fear the punishment that they could receive if they offend. Cesare Becarria, one of the founders of the deterrence theory, expressed his early conception of deterrence and argued that "the aim of punishment can only be to prevent the criminal committing new crimes against his countrymen and to keep others from doing likewise" (cited in Bean, 1981: 30) - the greater the punishment, the greater the deterrent. Punitive policies and practical applications of the deterrence theory have been formulated to regulate criminal behaviour in our society, but strikingly these policies do not seem to apply to police officers in England and Wales: convictions for police misconduct are exceptionally rare. Juries have been shown to be reluctant to prosecute officers who had been referred the Crown Prosecution Service from the IPCC. For example, investigations into the deaths in custody have led to 9 unlawful killing verdicts, and these police officers are yet to be convicted (House of Commons, 2013: 3). The process necessitates the IPPC to investigate the case and present it to the Crown Prosecution Service if it is felt that there are concerns of criminality. It is up to the criminal justice system, however, to prosecute these referred individuals. It is not the intention of this paper to scrutinise each referral to the CPS, nor is there the time or the space to go into detail, but what is clear $\mathrm{SAD} / \mathrm{JSR}$ 
is that juries either find it difficult or are unwilling to convict police officers. This affects public's confidence in the criminal justice system in general, police in particular, leading to the public's mistrust, suspicion of hostility towards law enforcers. This lack of confidence is especially visible among ethnic minorities: a 2005 Home Office study with the intention of revealing the extent of trust ethnic groups had towards the police reported that Black people had the lowest levels of trust towards the police at $65 \%$ in comparison to $80 \%$ of Whites and $79 \%$ of Asians (Home Office, 2005).

\section{WHAT MORE CAN BE DONE TO IMPROVE ACCOUNTABILITY?}

If internal and external investigations into police corruption fail miserably (the most obvious one being the IPCC which struggled to gain public confidence for many reasons as explained above), it then becomes obvious that something must be done to effectively deal with police misconduct. It must be asked. What are we not doing right?'. The first answer to that question, although it may become a surprise to many, is that the police in England and Wales is yet to develop a code of ethics that details the principles and standards of behaviour expected from personnel at the bottom of the hierarchy to the one at the top. It is difficult to come to terms with the fact that the police in England and Wales do not have a code of ethics that apply to all police forces across England and Wales: there are local standards that police officers are obliged to follow and these standards differ from region to region. A code of ethics on the national level would provide a framework to set and maintain the highest possible standards from everyone in policing.

Having outlined this need in policing in England and Wales for the expansion of police funding to the IPCC to meet increasing demand; an increase in the number of staff employed by agencies concerned with police accountability; and providing bigger sanctions for police-dishonesty it can also be said that today's police forces could benefit from increased use of technology in an attempt to increase the levels of supervision of police officers. It is already common in today's society to see members of the 
public recording their interaction with the police but when the method is deployed by the police, it raises serious questions about the privacy of individuals with whom the police interact. What would parents think when the police interact with their young children? How would women subject to domestic abuse feel when they call the police to their home following an incident? Such questions which lead to hesitation towards the introduction of body-worn cameras have led to the suggestion that officers should be allowed to switch their cameras on and off depending on the incident to which they are called. This suggestion is also however very contested: giving police officers the opportunity to switch off their cameras may still lead to police wrongdoing. Putting those controversies to one side, what is safe to say uncontested is that constantly recording body-worn cameras would hold each and every single police officer to account, ultimately acting as a deterrent. Visual recordings can be an independent witness. The recorded data could, then, be used as evidence in investigations led by concerned bodies or submitted to courts, resulting in fair and accurate verdicts. In the Rialto region of California, body-worn cameras have not only led to an $88 \%$ decrease in the number of complaints made against serving police officers but it also led to a $60 \%$ fall in the number incidents in which police officers used force (The Guardian, 2013). Although such reforms may lead police officers to the feeling that their own rights are violated by their superiors, they look promising in creating a policing service that is based on trust, respect, honesty and fairness with the bonus of reducing the amount of police-bureaucracy.

What can be safely recommended is the necessity of a whistleblowing culture within the police to improve police accountability. Although the elements of whistleblowing, the reporting of corruption or any unethical behaviour, are found under the Employment Rights Act 1996 which also apply to police personnel, such policy is yet to be morally embraced by police personnel despite the state's protection of officers against dismissal or any unfavourable treatment for making a disclosure. It is a rare 
scenario to see an officer reporting his/her colleague. Several explanations have been put forward to explain this reluctance: reporting officers may be deemed as being disloyal to their colleagues; whistle-blowers may fear harassment and lose other officers' respect. Bearing in mind that police officers are generally the first ones within the police to realise/witness police misconduct, it is essential that PCCs and chief police officers provide psychological support to officers to come forward and voice their concerns, and process the case professionally. 


\section{ÖZET}

Bu makale, İngiltere ve Galler'de polis hesap verebilirlik, gözetim ve denetim sisteminin gelişimini bilimsel literatürü inceleyerek araştırmaktadır. $\mathrm{Bu}$ makaleyle hesap verebilirliği iç güvenlik hizmetlerinde önemli bir ilke kabul eden sorumlu, profesyonel ve demokratik iç güvenlik kurumlarına, bu alanda bazı önemli kavramsal değerlendirmelerin tanımlanması yoluyla yardım edilmesi umut edilmektedir. İç güvenlik profesyonellerinin görevlerini yerine getirirken yetkilerini kötüye kullandıkları, her toplumda görülen bir olgudur. Bu makale, temel görevleri iç güvenlik kurumlarını gözetlemek ve denetlemek olan sivil gözetim organlarının İngiltere ve Galler'de kolluğun hesap verebilir olması için nasıl çalıştıklarını incelemektedir. Çalışmada kolluk üzerinde gerekli denetim ve denge mekanizmaları kurulmadığı takdirde, polise verilen yetki ve salahiyetlerin yozlaşmaya ve istismara yol açabildiği temel varsayımından hareket edilmiştir. 


\section{REFERENCES}

BBC News. (2007). Police Condemn 'Target Culture'. (available at http://news.bbc.co.uk/1/hi/uk/6656411.stm, access on 03.09.2014).

BBC News. (2012). PCC Results: Breakdown. (available at http://www.bbc.co.uk/news/uk-politics20361626, access on 03.09.2014).

BBC News. (2013). US Boy Carrying Replica Gun Shot Dead by California Police, (available at http://www.bbc.co.uk/news/world-us-canada-24648974, access on 01.09.2014).

Bean, P. (1981). Punishment: A Philosophical and Criminological Inquiry. Oxford: Martin Robertson.

Berry, J. (2009). Reducing Bureaucracy in Policing: Interim Report. London: Home Office.

CLINKS. (2012). Safer Future Communities: Empowering Local Voluntary and Community Partnership. Policy Briefing No 6. North East, UK: VONNE.

Daily Mail (2010). Minor 'Crimes' of the Middle Classes Raking in a $\$ 400 m$ Fortune for Cash-Hungry Councils. (available at http://www.dailymail.co.uk/news/article-1244038/The-easy-targets-hit400m-minor-crimes-middle-classes-raking-fortune-cash-hungrycouncils.html\#ixzzlzwgRyaHP, access on 02.09.2014).

Flanagan, R. (2008). The Review of Policing: Final Report. London: Home Office.

HMIC. (2011). Without Fear or Favour - a Review of Police Relationships. London: HMIC.

Home Office. (1999). The Stephen Lawrence Inquiry: Report of an Inquiry by Sir William Macpherson of Cluny. London: Home Office.

Home Office. (2003). Policing: Building Safe Communities Together. London: HMSO.

Home Office. (2005). Statistics on Race and the Criminal Justice System 2004: A Home Office Publication under Section 95 of the Criminal Justice Act 1991. London: Home Office.

Home Office. (2009). Protecting the Public: Supporting the Police to Succeed. London: Home Office. 
Home Office. (2010). Policing in the 21st Century: Reconnecting Police and the People Presented to Parliament by the Secretary of State for the Home Department by Command of HM. London: Home Office.

House of Commons. (2013). Written Evidence Submitted by the Independent Police Complaints. Commission [IPCC 06], Parliament UK- Home Office.

House of Commons. (2013b). Independent Police Complaints Commission: Eleventh Report of Session 2012-13. Parliament UK- Home Office.

IPCC. (2011). Police Complaints: Statistics for England and Wales 2010/11. IPCC Research and Statistics Series: Paper 22, London: IPCC.

IPCC. (2012). Corruption in the Police Service in England and Wales: Second report -A Report Based on the IPCC's Experience from the 2008-2011. London: IPCC.

IPCC. (2012a). Police Complaints 2011/2012. London: IPCC.

IPCC. (2012b). Police Complaints: Statistics for England and Wales, 2011/12. London: IPCC.

IPCC. (2012c). Deaths During or Following Police Contact: Statistics for England and Wales, 2011/12. London: IPCC.

Lewis, C. (1999). Complaints against Police: The Politics of Reform. Sydney, Australia: Hawkins Press.

Local Government Association. (2008). Answering to You: Policing in the 21st Century. London: LGA Publications.

Mawby, R. and Wright, A. (2005). Police Accountability in the United Kingdom. Written for the Keel University, UK: Commonwealth Human Rights Initiative.

NAO. (2014). What We Do. (available at http://www.nao.org.uk/about-us/what-we-do/, access on 03.09.2014).

NAO. (2014a). Police Sccountability: Landscape Review. Report by the Comptroller and Auditor General: Home Office. 